\title{
$\triangle$-AMINOLEVULINATE SYNTHESIS IN GREENING BARLEY V. THE STRUCTURE OF GLUTAMATE 1-SEMIALDEHYDE
}

\author{
by \\ GUNNAR HOUEN'), SIMON P. GOUGH \\ and \\ C. GAMINI KANNANGARA \\ Department of Physiology, Carlsberg Laboratory, \\ Gamle Carlsberg Vej 10, DK-2500 Copenhagen, Valby \\ "Chemical Laboratory II, H.C. Ørsted Institute, University of Copenhagen, \\ Universitetsparken 5, DK-2100 Copenhagen Ø. \\ Present address: \\ Carlsberg Biotechnology Ltd. A/S, \\ Tagensvej 16, DK-2200 Copenhagen N.
}

Keywords: Mass spectrometry, nuclear magnetic resonance, glutamate semialdehyde aminotransferase, chlorophyll synthesis

Glutamate l-semialdehyde diethyl acetal was synthesised and its structure confirmed by mass and nuclear magnetic resonance spectroscopy. Acid hydrolysis of this substance gave glutamate 1-semialdehyde, the substrate for the enzyme glutamate 1-semialdehyde aminotransferase. It is confirmed that glutamate 1-semialdehyde is the immediate precursor of $\delta$-aminolevulinate in the chlorophyll biosynthetic pathway.

\section{INTRODUCTION}

Glutamate is the precursor of $\delta$-aminolevulinate in the chlorophyll pathway in greening barley leaves (3). The enzymes converting glutamate to $\delta$-aminolevulinate are localised in the plastid stroma (2). Glutamate is converted via glutamate 1-semialdehyde into $\delta$-aminolevulinate. This last step involves an internal transamination and is catalysed by the enzyme glutamate 1-semialdehyde aminotransferase (E.C.5.4.3.8) (4). This enzyme has been purified to homogeneity (5). It specifically converts glutamate 1-semialdehyde into $\delta$-aminolevulinate in the absence of added cofactors (4). The glutamate 1-semialdehyde used in previous studies was synthesised by $\mathrm{Pd}$ catalysed hydrogenation of $\mathrm{N}$-CBz-L-glutamate 5-benzyl ester 1-acid chloride. Glutamate 1-semialdehyde is stable in dilute solution at acidic $\mathrm{pH}$. In concentrated solution or at alkaline $\mathrm{pH}$ the aminoaldehyde is readily polymerised to give an enzymically inactive product. Consequently attempts to obtain glutamate 1-semialdehyde in concentrations suitable for the determination of its structure were not 
G. Houen et al.: Glutamate 1-semialdehyde

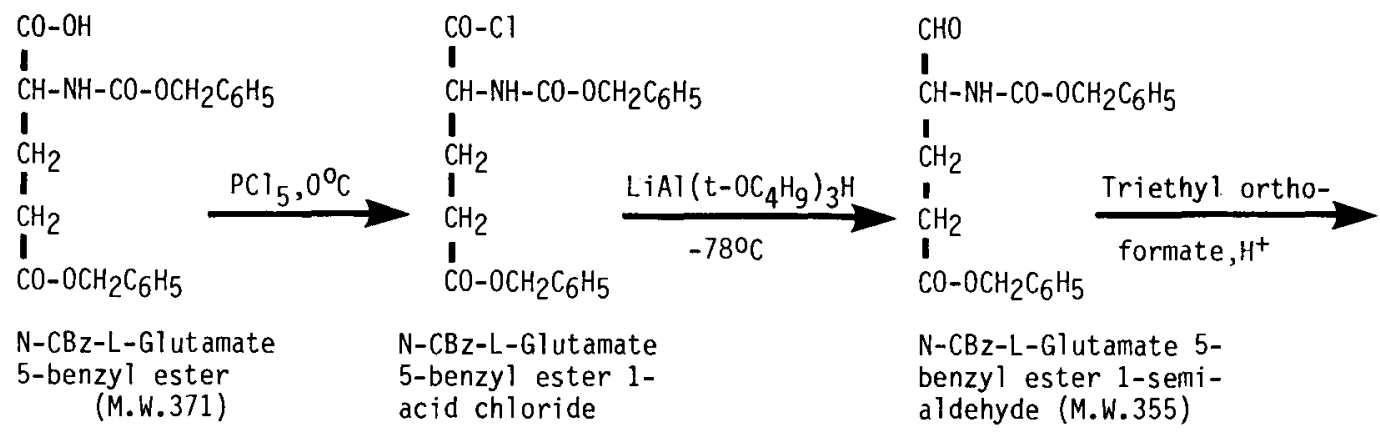

\begin{tabular}{|c|c|c|c|c|}
\hline $\begin{array}{l}\mathrm{CH}-\left(\mathrm{OC}_{2} \mathrm{H}_{5}\right)_{2} \\
\mathrm{CH}-\mathrm{NH}-\mathrm{CO}-\mathrm{OCH}_{2} \mathrm{C}_{6} \mathrm{H}_{5} \\
\mathrm{CH}_{2} \\
\mathrm{CH}_{2} \\
\mathrm{CO}_{-} \mathrm{OCH}_{2} \mathrm{C}_{6} \mathrm{H}_{5}\end{array}$ & $\frac{\mathrm{Pd} / \mathrm{C}}{1,4-\mathrm{Cycl} \text { ohexadiene }}$ & $\begin{array}{l}\mathrm{CH}-\left(\mathrm{OC}_{2} \mathrm{H}_{5}\right)_{2} \\
\mathbf{C H}-\mathrm{NH}_{2} \\
\mathrm{CH}_{2} \\
\mathrm{CH}_{2} \\
\mathrm{CH}_{2} \\
\mathrm{COOH}^{\mathrm{COH}}\end{array}$ & $\frac{\text { Acid }}{\text { Hydrolysis }}$ & $\begin{array}{l}\mathrm{CHO} \\
\mathbf{I} \\
\mathrm{CH}-\mathrm{NH}_{2} \\
\mathrm{CH}_{2} \\
\mathrm{CH}_{2} \\
\mathrm{CH}_{2} \\
\mathrm{I} \\
\mathrm{COOH}\end{array}$ \\
\hline $\begin{array}{l}\text { N-CBz-L-Glutamate } \\
\text { ester 1-semialdehy } \\
\text { ethyl acetaT (M.W. }\end{array}$ & $\begin{array}{l}\text { 5-benzyl } \\
\text { de di- } \\
429 \text { ) }\end{array}$ & $\begin{array}{l}\text { L-GIutamate 1-semi } \\
\text { aldehyde diethyl } \\
\text { acetal (M.W.205) }\end{array}$ & & $\begin{array}{l}\text { L-Glutamate } \\
\text { 1-semial dehyde }\end{array}$ \\
\hline
\end{tabular}

Figure 1 . Synthetic route to glutamate 1-semialdehyde. M.W = molecular weight.

successful. This has even caused some doubt about glutamate 1-semialdehyde as a precursor of chlorophyll (6). We therefore synthesised a stable derivative, the diethyl acetal of glutamate 1-semialdehyde and confirmed its structure by mass and nuclear magnetic resonance spectroscopy. We also demonstrate that glutamate 1-semialdehyde was liberated by acid hydrolysis of the acetal.

\section{MATERIALS AND METHODS}

\subsection{Chemicals}

$\mathrm{N}$-CBz-L-glutamate 5-benzyl ester was obtained from Bachem, Switzerland. 1,4-cyclohexadiene was from Fluka, Switzerland.

\subsection{Synthesis of glutamate 1-semialdehyde diethyl acetal}

The reactions used for the synthesis of glutamate 1-semialdehyde diethyl acetal from N-CBzL-glutamate 5-benzyl ester and its conversion to free semialdehyde are summarised in Figure 1.
N-CBz-L-glutamate 5-benzyl ester (500 mg) was dissolved in $4 \mathrm{ml}$ of dry ether and converted to the acid chloride by reacting with $500 \mathrm{mg}$ of $\mathrm{PCl}_{5}$ for 30 minutes at $0{ }^{\circ} \mathrm{C}$. The acid chloride which precipitated as a white crystalline mass was collected by filtration and washed with hexane. The N-CBz-L-glutamate 5-benzyl ester 1-acid chloride was dissolved without further purification in $2 \mathrm{ml}$ of diethylene glycol dimethyl ether (diglyme) and reduced to N-CBz-L-glutamate 5-benzyl ester 1-semialdehyde according to (1). The reduction was carried out with freshly prepared $\mathrm{LiAl}\left(\mathrm{t}-\mathrm{OC}_{4} \mathrm{H}_{9}\right)_{3} \mathrm{H}$. The reductant was prepared by adding $445 \mathrm{mg}$ of t-butyl alcohol dissolved in $2.5 \mathrm{ml}$ of diethyl ether to a solution of $\mathrm{LiAlH}_{4}(76 \mathrm{mg})$ in $5 \mathrm{ml}$ of diethyl ether over a period of one hour. The $\operatorname{LiAl}\left(\mathrm{t}-\mathrm{OC}_{4} \mathrm{H}_{9}\right)_{3} \mathrm{H}$ was formed as white precipitate. It was decanted from the solvent and dissolved in $2 \mathrm{ml}$ of diglyme. The solution of the hydride was added dropwise over a period of one hour to the solution of N-CBz-L-glutamate 5-benzyl ester 1-acid 
chloride under a stream of nitrogen in acetonesolid $\mathrm{CO}_{2}$ at $-78{ }^{\circ} \mathrm{C}$. The reaction mixture was removed from the cold bath, allowed to warm up to room temperature and after half an hour poured onto ice. N-CBz-L-glutamate 5-benzyl ester 1-semialdehyde separated as a white precipitate and was collected by filtration. Derivatisation with 2,4-dinitrophenylhydrazine gave an orange precipitate (m.p. $63-65^{\circ} \mathrm{C}$, uncorrected). The aldehyde was then lyophilized and its mass spectrum determined. N-CBz-L-glutamate 5-benzyl ester 1-semialdehyde was dissolved in $1.75 \mathrm{~g} \mathrm{5 \%}$ ethanolic $\mathrm{HCl}$ and $0.75 \mathrm{~g}$ triethyl orthoformate was added. The mixture was stirred overnight at room temperature and $2 \mathrm{~g} \mathrm{Na}$ dissolved in $2 \mathrm{ml}$ of ethanol was added with stirring. The reaction mixture was diluted with water, extracted three times with diethyl ether, the extracts dried and the ether evaporated to give N-CBz-L-glutamate 5-benzyl ester 1-semialdehyde diethyl acetal as a clear oil $(60 \mathrm{mg})$. The yield was $10.3 \%$. The structure was confirmed by mass spectroscopy and by ${ }^{13} \mathrm{C}$ nuclear magnetic resonance spectroscopy (section 3.1).

L-glutamate 1-semialdehyde diethyl acetal was prepared by removing the carbobenzoxy and benzyl ester protective groups as follows. Sixty $\mathrm{mg}$ of the N-CBz-L-glutamate 5-benzyl ester 1-semialdehyde diethyl acetal was dissolved in 1 $\mathrm{ml}$ of absolute ethanol. Twenty-five $\mathrm{mg}$ of $5 \%$ $\mathrm{Pd}-\mathrm{C}$ and $1 \mathrm{ml}$ of 1,4 cyclohexadiene was added. The mixture was stirred for $2 \mathrm{~h}$ while nitrogen was bubbled through and then filtered. The residue was extracted twice with water and the extracts filtered and lyophilised to give white crystals $(3 \mathrm{mg})$ of L-glutamate-1-semialdehyde diethyl acetal. Evaporation of the filtrate recovered $47 \mathrm{mg}$ of unreduced starting material. The overall yield of glutamate 1-semialdehyde diethyl acetal was $1.1 \%$ and its structure was analysed by mass spectroscopy and proton magnetic resonance spectroscopy.

\subsection{Other methods}

Mass spectra were obtained with an AEI-MS 9 spectrometer ( $70 \mathrm{eV}$ ionisation potential, direct insertion of the sample in the ion source). ${ }^{\prime} \mathrm{H}$ and ${ }^{13} \mathrm{C}$-nuclear magnetic resonance spectra were obtained using a Fourier transform, $90 \mathrm{MHz}$, JEOL FX 90 instrument. Glutamate 1-semialdehyde aminotransferase assays were performed as described in (7). Thin layer chromatography was performed with a stationary phase of silica gel (Machery Nagel Sil G-25) using a solvent system of butanol/acetic acid/water (60:20:20, v/v/v). Saturated dinitrophenylhydrazine in $2 \mathrm{M}-\mathrm{HCl}$ was used as a spray to detect acetals and aldehydes.

\section{RESULTS}

\subsection{N-CBz-L-glutamate 5-benzyl ester 1-semialdehyde and its diethyl acetal}

The mass spectrum of the product obtained by reduction of N-CBz-L-glutamate 5-benzyl ester 1-acid chloride with $\mathrm{LiAl}\left(\mathrm{t}-\mathrm{OC}_{4} \mathrm{H}_{9}\right)_{3} \mathrm{H}$ suggested that it was $\mathrm{N}-\mathrm{CBz}-\mathrm{L}$-glutamate 5-benzyl ester 1 -semialdehyde. The set of ions observed in the mass spectrum had the following mass to charge ratios ( $\mathrm{m} / \mathrm{e})$ and relative intensities and are attributed to the molecular ion (M+), or fragment ions as indicated in parentheses: $355,0.01 \%$ (M.); 337, 0.01\% (M - $\left.\mathrm{H}_{2} \mathrm{O}\right) ; 326,6 \%$

(M - CHO); 282, 6.4\% (M - CHO - $\left.\mathrm{CO}_{2}\right) ; 249$, $1.4 \%\left(\mathrm{M}-\mathrm{OCH}_{2} \mathrm{C}_{6} \mathrm{H}_{5}\right) ; 192,2.6 \%$

(M - $\mathrm{CH}_{2} \mathrm{CH}_{2} \mathrm{COOCH}_{2} \mathrm{C}_{6} \mathrm{H}_{5}$ ); $181,3 \%$

$\left(\mathrm{HOCH}_{2} \mathrm{NHCOOCH}_{2} \mathrm{C}_{6} \mathrm{H}_{5}\right) ; 151,3 \%$

$\left(\mathrm{NH}_{2} \mathrm{COOCH}_{2} \mathrm{C}_{6} \mathrm{H}_{5}\right) ; 108,30 \%\left(\mathrm{HOCH}_{2} \mathrm{C}_{6} \mathrm{H}_{5}\right)$; $107,30 \%\left(\mathrm{OCH}_{2} \mathrm{C}_{6} \mathrm{H}_{5}\right) ; 91,100 \%\left(\mathrm{CH}_{2} \mathrm{C}_{6} \mathrm{H}_{5}\right)$.

The mass spectrum of N-CBz-L-glutamate 5-benzyl ester 1-semialdehyde diethyl acetal and the assignment of the fragments are as follows: 429, <1\% (M.); 414, <1\% (M - $\left.\mathrm{CH}_{3}\right) ; 368,<1 \%$

$\left(\mathrm{M}-\mathrm{CH}_{3}-\mathrm{C}_{2} \mathrm{H}_{5} \mathrm{OH}\right) ; 279,<1 \%$

$\left(\mathrm{M}-\mathrm{NHCOOCH}_{2} \mathrm{C}_{6} \mathrm{H}_{5}\right) ; 188,<1 \%$

(M - $\mathrm{NHCOOCH}_{2} \mathrm{C}_{6} \mathrm{H}_{5}-\mathrm{CH}_{2} \mathrm{C}_{6} \mathrm{H}_{5}$ ); 142, 25\%

(188- $\mathrm{CH}_{3} \mathrm{CH}_{2} \mathrm{OH}$, metastable at 107.3$) ; 114,15 \%$ (142 - $\mathrm{C}_{2} \mathrm{H}_{4}$, metastable at 91.5$) ; 103,100 \%$ $\left(\mathrm{CH}\left(\mathrm{OCH}_{2} \mathrm{CH}_{3}\right)_{2}\right) ; 91,30 \%\left(\mathrm{CH}_{2} \mathrm{C}_{6} \mathrm{H}_{5}\right) ; 84,48 \%$ $\left(114-\mathrm{CH}_{2} \mathrm{O}\right) ; 75,68 \%\left(103-\mathrm{C}_{2} \mathrm{H}_{4}\right)$.

The ${ }^{13} \mathrm{C}$-nuclear magnetic resonance spectrum of N-CBz-L-glutamate 5-benzyl ester 1-semialdehyde diethyl acetal in $\mathrm{CDCl}_{3}$ is shown in Figure 2. The ${ }^{13} \mathrm{C}$ resonances in ppm and the assignation of the carbon atom are as follows: 178.66, singlet $1 \mathrm{C}\left(-\mathrm{CH}_{2} \mathrm{COO}-\right)$; 141.19 , singlet $1 \mathrm{C}$ (-NHCOO-); 128.34-126.90, multiplet 12C (two $\left.\mathrm{C}_{6} \mathrm{H}_{5}\right) ; 104.77$, singlet $1 \mathrm{C}\left(-\mathrm{CH}\left(\mathrm{OCH}_{2} \mathrm{CH}_{3}\right)_{2}\right)$; 72.07, singlet $1 \mathrm{C}(-\mathrm{CHNH}) ; 64.89$, singlet $1 \mathrm{C}$ $\left(-\mathrm{COOCH}_{2} \mathrm{C}_{6} \mathrm{H}_{5}\right) ; \quad 63.45$, singlet $1 \mathrm{C}$ $\left(-\mathrm{COO} \underline{\mathrm{C}} \mathrm{H}_{2} \mathrm{C}_{6} \mathrm{H}_{5}\right) ; 56.27$ singlet $2 \mathrm{C}\left(\mathrm{OCH}_{2} \mathrm{CH}_{3}\right)$; 


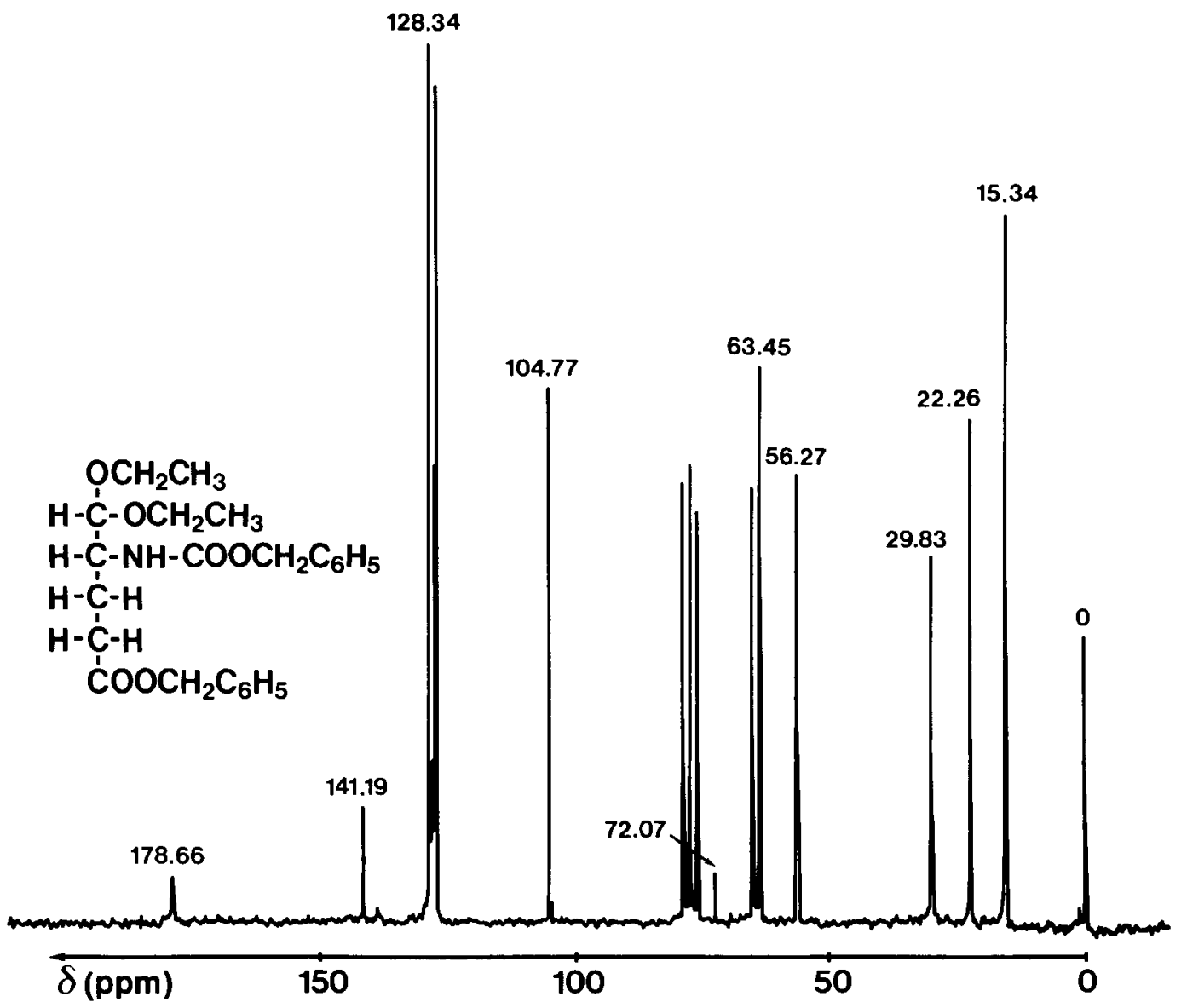

Figure 2. ${ }^{13} \mathrm{C}$-nuclear magnetic resonance spectrum of N-CBz-L-glutamate 5-benzyl ester 1-semialdehyde diethyl acetal in $\mathrm{CDCl}_{3}$.

29.83, singlet $1 \mathrm{C}$ (- $\left.\mathrm{CH}_{2} \mathrm{COO}-\right) ; 22.26$, singlet $1 \mathrm{C}$ $\left(-\mathrm{CH}_{2} \mathrm{CH}_{2}-\right) ; 15.34$, singlet $2 \mathrm{C}\left(-\mathrm{OCH}_{2} \mathrm{CH}_{3}\right)$.

\subsection{Characterisation of glutamate}

\section{1-semialdehyde diethyl acetal}

The mass spectrum of glutamate 1-semialdehyde diethyl acetal and the assignation of the fragments are as follows, $\mathrm{m} / \mathrm{e}$, relative intensities: 205, 0.8\%(M+); 149, 10\% (M - $\mathrm{C}_{2} \mathrm{H}_{4}$ $\left.\mathrm{C}_{2} \mathrm{H}_{4}\right) ; 142,10 \%\left(\mathrm{M}-\mathrm{H}_{2} \mathrm{O}-\mathrm{CH}_{3} \mathrm{CH}_{2} \mathrm{O}\right) ; 126,7 \%$ $\left(\mathrm{M}-\mathrm{CH}_{3} \mathrm{CH}_{2} \mathrm{O}-\mathrm{OH}-\mathrm{NH}_{3}\right) ; 103,22 \%$ $\left(\mathrm{CH}\left(\mathrm{OCH}_{2} \mathrm{CH}_{3}\right)_{2}\right) ; 86,8 \%\left(149-\mathrm{H}_{2} \mathrm{O}-\mathrm{COOH}\right)$; $84,8 \%\left(142-\mathrm{CO}_{2}-\mathrm{CH}_{2}\right) ; 75,43 \%\left(103-\mathrm{C}_{2} \mathrm{H}_{4}\right.$, metastable at 54.6); 64, 43\% $\left(\mathrm{NH}_{3} \mathrm{CH}(\mathrm{OH})_{2}\right) ; 45$, $100 \%\left(\mathrm{CH}_{3} \mathrm{CH}_{2} \mathrm{O}\right)$.
The proton magnetic resonance spectrum of glutamate 1-semialdehyde diethyl acetal is given in Figure 3. The signals are assigned as follows. At $1.23-1.06 \mathrm{ppm}$ two triplets $6 \mathrm{H}$ from the two $\mathrm{CH}_{3} ;$; 2.46-1.94, multiplet $4 \mathrm{H}$ from $-\mathrm{CH}_{2} \mathrm{CH}_{2}-$; 3.62-3.78, multiplet $6 \mathrm{H}$ from $1-\mathrm{CH}, 2-\mathrm{CH}$ and $-\mathrm{OCH}_{2} \mathrm{CH}_{3}$.

\subsection{Acid hydrolysed glutamate 1-semialdehyde diethyl acetal}

Glutamate 1-semialdehyde diethyl acetal ( 300 $\mu \mathrm{g}$ ) in $300 \mu \mathrm{l} 8.5 \%$ phosphoric acid was hydrolysed in a boiling water bath for 30 minutes. Liberation of glutamate semialdehyde was determined enzymatically. Hydrolysate equivalent to 


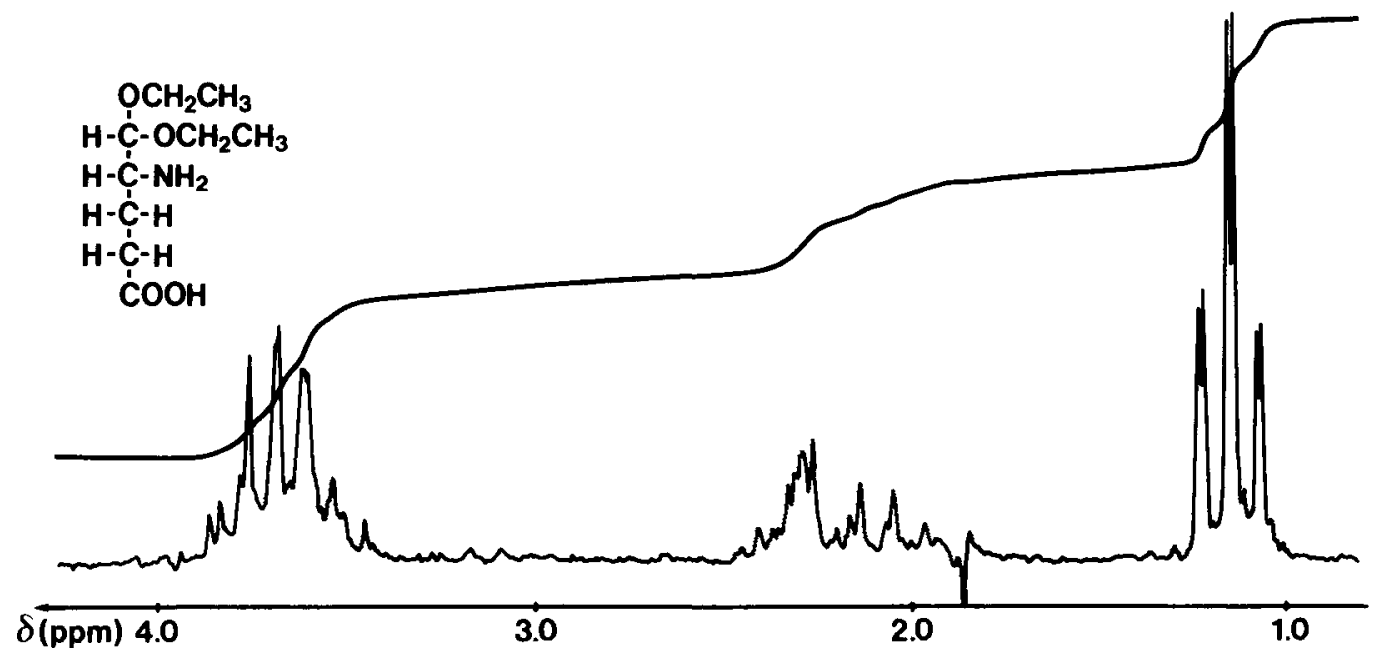

Figure 3. The proton magnetic resonance spectrum of glutamate 1-semialdehyde diethyl acetal in $\mathrm{D}_{2} \mathrm{O}$.

$0.5 \mu$ mole of acetal was used as substrate in the glutamate semialdehyde aminotransferase assay and gave $\delta$-aminolevulinate ( 7 nmoles).

Glutamate 1-semialdehyde prepared directly by Pd catalyzed hydrogenation of N-CBz-L-glutamate 5-benzyl ester 1-acid chloride according to (4) and the glutamate 1-semialdehyde prepared by hydrolysis of the diethyl acetal were indistinguishable when analysed by silica gel thin layer chromatography. Glutamate 1-semialdehyde migrated with an $R_{f}$ of 0.53 whereas the $R_{f}$ of glutamate 1-semialdehyde diethyl acetal was 0.62 and that of glutamate 0.39 .

\section{DISCUSSION}

The results presented in this paper show that glutamate 1-semialdehyde diethyl acetal can be synthesised as a stable product. The structure of the synthetic glutamate 1-semialdehyde diethyl acetal and of the synthetic intermediates were confirmed by mass spectroscopy and nuclear magnetic resonance spectroscopy. In the mass spectrum of L-glutamate 1-semialdehyde diethyl acetal an ion was observed at $\mathrm{m} / \mathrm{e}=205$, corresponding to the expected molecular weight. A fragment ion, relative intensity $10 \%, \mathrm{~m} / \mathrm{e}=149$, formed by loss of $2\left(\mathrm{C}_{2} \mathrm{H}_{4}\right)$ was attributable to the dihydrate of glutamate 1-semialdehyde. Func- tional groups of the glutamate 1-semialdehyde diethyl acetal molecule i.e. diethyl acetal, amine and carboxylic acid, could be identified in the mass spectrum from the following peaks. A peak with an $\mathrm{m} / \mathrm{e}$ ratio of 103 was attributed to an ion containing the diethyl acetal functional grouping. A peak $(\mathrm{m} / \mathrm{e}=126)$ was attributed to loss of $\mathrm{NH}_{3}, \mathrm{OH}$ and $\mathrm{CH}_{3} \mathrm{CH}_{2} \mathrm{O}$ from the parent ion, indicating the presence of an amino group. Finally, $\mathrm{m} / \mathrm{e}=86$ was attributed to the loss of $\mathrm{COOH}$ and $\mathrm{H}_{2} \mathrm{O}$ from the parent ion. The proton magnetic resonance spectrum showed a signal, in the form of a double triplet, at $1.23-1.06 \mathrm{ppm}$ downfield from trimethyl silane. This was attributed to the six methyl protons of the diethyl acetal. The splitting of the triplet establishes the presence of a neighbouring asymmetric carbon as expected in L-glutamate 1-semialdehyde diethyl acetal. The integrated peak area of the double triplet was used to calculate the total number of protons as 16 . The multiplet signal at 2.46-1.94 ppm was attributed to the four protons on carbon 3 and 4 . In the spectrum of monosodium glutamate a multiplet signal with the same shifts are seen for the analogous protons (8). The six proton multiplet signal at $3.62-3.78 \mathrm{ppm}$ arises from the protons on carbons 1 and 2 and the four methylene protons of the diethyl acetal. The 
chemical synthesis and these spectra establish the structure of the synthetic product as glutamate 1-semialdehyde diethyl acetal.

Glutamate 1-semialdehyde was liberated from glutamate 1-semialdehyde diethyl acetal by boiling with dilute phosphoric acid. Boiling in dilute acid is generally used to hydrolyse acetals to the parent aldehyde (9). The product of acid hydrolysis has been established as a specific substrate for the enzyme glutamate 1-semialdehyde aminotransferase. The enzyme preparations we used had no detectable dioxovalerate transaminase activity. Based on the chemical and enzymic data, the formation of a different five carbon compound e.g., dioxovalerate, during acid hydrolysis is excluded. Furthermore, the stroma of barley plastids has very low levels of dioxovalerate transaminase activity and an amino donor is required to demonstrate its activity. As observed by MEISCH and MAUS (6) glutamate 1 -semialdehyde polymerises rapidly in concentrated solution which led these authors to the erronous conclusion that glutamate 1-semialdehyde could not exist in stable form and therefore is precluded as precursor of chlorophyll. However, we have kept dilute acidic solutions (up to $10 \mathrm{~mm}$ ) frozen at $-20^{\circ} \mathrm{C}$ for several months without appreciable breakdown as determined by the enzymatic assay. On the other hand, we consider that glutamate 1-semialdehyde diethyl acetal is a better compound for bulk storage. In the present study the acetal was obtained in very poor yield and attempts are being made to improve the yield. The enzymes involved in the conversion of glutamate to glutamate 1-semialdehyde have been isolated from the stroma of greening barley plastids (7). The partially purified enzymes convert $56 \%$ of added ${ }^{14} \mathrm{C}$-glutamate to glutamate 1 -semialdehyde in vitro (7). We maintain (4) that glutamate 1-semialdehyde is the immediate precursor of $\delta$-aminolevulinate in the chlorophyll biosynthetic pathway.

\section{ACKNOWLEDGEMENTS}

We wish to thank Professor Diter von WETTSTEIN and Dr. DAVID SIMPSON for a critical reading of the manuscript. Ms Nina Rasmussen is thanked for drawing the figures, Ms ANN-SoFI Steinholtz for photography and Ms HaNNE THEM NIELSEN for typing the manuscript.

\section{REFERENCES}

1. Brown, H.C. \& B.C.S. RaO: A new aldehyde synthesis - The reduction of acid chlorides by lithium tri-t-butoxyaluminohydride. J. Amer. Chem. Soc. 80, 5377-5380 (1958)

2. Gough, S.P. \& C.G. Kannangara: Synthesis of $\delta$-aminolevulinate by a chloroplast stroma preparation from greening barley leaves. Carlsberg Res. Commun. 42, 459-464 (1977)

3. Kannangara, C.G. \& S.P. Gough: Synthesis of $\delta$-aminolevulinic acid and chlorophyll by isolated chloroplasts. Carlsberg Res. Commun. 42, 441-457 (1977)

4. Kannangara, C.G. \& S.P. Gough: Biosynthesis of $\delta$-aminolevulinate in greening barley leaves. Glutamate 1-semialdehyde aminotransferase. Carlsberg Res. Commun. 43, 185194 (1978)

5. Kannangara, C.G., S.P. Gough \& C.R. GiRNTH: $\delta$-Aminolevulinate synthesis in greening barley. 2. Purification of enzymes. In: Photosynthesis V. Chloroplast development. G. Akoyunoglou ed. Balaban International Science Services, Philadelphia, pp. 117-127

6. Meisch, H.-U. \& R. Maus: Untersuchungen zur Synthese und biologischen Bedeutung von Glutaminsäure-1-semialdehyd als Vorstufe der Chlorophylle. Z. Naturforsch. 38C, 563-570 (1983)

7. WANG, W.-Y., S.P. Gough \& C.G. KaNNANGARA: Biosynthesis of $\delta$-aminolevulinate in greening barley leaves. IV. Isolation of three soluble enzymes required for the conversion of glutamate to $\delta$-aminolevulinate. Carlsberg Res. Commun. 46, 243-257 (1981)

8. Varian Associates: Monosodium glutamate. In: Varian High Resolution NMR Spectra Catalogue. Vol. 2, spectra no. 435 (1963)

9. Veibel, S.: Acetals. In: The identification of organic compounds, seventh edition G.E.C. Gad, Copenhagen. pp. 260 (1961) 